\title{
GENETIC DIVERSITY BY RAPD IN FOUR POPULATIONS OF ROHU Labeo rohita
}

\author{
Md. Alamgir Kabir ${ }^{*}$, Mohammad Shamsur Rahman¹, Mahmuda Begum², Md. Hasan
}

\section{Faruque $^{1}$}

'Department of Fisheries, University of Dhaka, Dhaka 1000, Bangladesh

${ }^{2}$ Zoology Section, Bangladesh Council of Scientific and Industrial Research (BCSIR), Dhaka 1205, Bangladesh

*Corresponding Author, Email: makabir@du.ac.bd

\section{ARTICLE INFO}

Received: 20 September 2016

Received in revised form: 17 November 2016

Accepted: 21 Nobember 2016

Available online: 19 December 2016

\begin{abstract}
Genetic diversity in four geographically distinct rohu (Labeo rohita) populations such as rohu Khulna, rohu India, rohu Faridpur and rohu Barisal was determined by RAPD. The banding pattern showed that rohu India was genetically different from the rest three. A total of 87 bands were found in four rohu populations where 35 bands were polymorphic, indicating $48.38 \%$ polymorphisms with an average of 12 bands per primer. The molecular size of amplified DNA fragments ranged from 400 to 1250 bp. Eight unique bands were observed in the four populations of which six were found in rohu Indian population. The genetic distance was highest $(0.7221)$ and genetic identity was lowest $(0.4857)$ between rohu India and rohu Barisal populations. Among three local varieties, the lowest genetic distance and highest genetic identity were found between rohu Khulna and rohu Faridpur populations. The UPGMA dendrogram segregated four populations of rohu into three major clusters - C1, C2 and C3. Rohu India was positioned at a fully different cluster - C3, rohu Khulna was placed in $\mathrm{C} 2$ and the rest two populations in $\mathrm{C} 1$.
\end{abstract}

\section{Keywords: \\ RAPD \\ Genetic diversity \\ Labeo rohita}

Kabir, M. A., Rahman, M. S., Begum, M., Faruque, M. F. (2017): Genetic diversity by RAPD in four populations of rohu Labeo rohita. Croatian Journal of Fisheries, 75, 12-17. DOI: 10.1515/cjf-2017-0003.

\section{INTRODUCTION}

Labeo rohita (Hamilton, 1822), locally known as rohu, is the most important among the Indian major carp species cultured in Bangladesh, contributing to $10.97 \%$ of the total inland production (FRSS, 2016). This species is also one of the most cultured freshwater fish in Bangladesh as well as Sri Lanka, China, Philippines, Malaysia, Nepal and some other countries of Africa (FAO, 2006). In Bangladesh, this fish is considered a delicacy and rich source of protein (Rahman, 2005). L. rohita has high market demand and value not only in Bangladesh but also in other countries with production that does not meet the demand. Due to a high market demand, this fish is imported from India and Myanmar (Burma), known as Indian or Burmese rohu in Bangladesh. Import of this fish is not self-dependent and production should be increased. For this purpose an improved breeding program should be undertaken. For successful breeding program a wide range of genetic diversity within population is required (Schierwater et al., 1994). Unfortunately there is a limited amount of data available on the genetic diversity of rohu in Bangladesh. It is known that the geographical distance may create genetic diversity (Dayu et al., 2007). The geographic distances are directly correlated with genetic diversity (Rahman et al., 
2009). In Bangladesh the artificially propagated rohu has been cultured in different geographical regions such as Khulna, Barisal and Faridpur, etc., in different closed ponds. Sometimes these fishes are reared and used as brood fish for breeding program but these fishes may come from the same brood population or same tributary. It is necessary to determine the genetic variability of rohu fish found in different geographical culture areas. In this research three culture areas such as Barisal, Faridpur, Khulna and the imported rohu India were selected to determine the genetic diversity based on RAPD. It is a simple, fast and sensitive technique that can identify genetic variation without prior knowledge of DNA sequences and has been widely used in fisheries studies (Akter et al., 2010) to identify the genetic diversity and conservation of fish populations (Almeida et al., 2001). Thus the present study was conducted to elucidate the genetic diversity among three rohu populations collected from geographically distant locations and one imported from India.

\section{MATERIALS AND METHODS}

\section{Sample collection and isolation of total genomic DNA}

Caudal fins of artificially propagated 10 rohu fishes of each location were randomly collected from different local markets of Dhaka City such as Swarighat, Aanando Bazar, Polashi Bazar and New Market, and stored in 95\% ethanol. Approximately, the mean length and weight of rohu India was $2.90 \pm 0.12 \mathrm{~kg} \& 53.9 \pm 2.18 \mathrm{~cm}$, rohu Khulna was $1.22 \pm 0.18 \mathrm{~kg} \& 39.9 \pm 1.91 \mathrm{~cm}$, rohu Faridpur was $1.20 \pm 0.15 \mathrm{~kg} \& 39.6 \pm 1.84 \mathrm{~cm}$ and rohu Barisal was $1.20 \pm 0.17 \mathrm{~kg} \& 40.1 \pm 1.85 \mathrm{~cm}$. These four populations were collected from different locations viz. Khulna $\left(22^{\circ} 490 \mathrm{~N} 89^{\circ} 330 \mathrm{E}\right)$, Faridpur $\left(23.50^{\circ} \mathrm{N} 89.83^{\circ} \mathrm{E}\right)$ and Barisal $\left(22^{\circ} 480 \mathrm{~N} 90^{\circ} 30 \mathrm{O}\right.$ ) in Bangladesh and one was imported from India, known as Indian rohu. The distance from Khulna to Faridpur is $137.8 \mathrm{~km}$, from Khulna to Barisal is $139.4 \mathrm{~km}$ and from Faridpur to Barisal is $128.4 \mathrm{~km}$ (www.google.com.bd/maps/ accessed on 16 July 2016). Modified CTAB method (Doyle, 1987) was used to isolate the total genomic DNA from pooled samples of rohu. Approximately $30 \mathrm{mg}$ of caudal fin tissue was used to isolate the DNA. Caudal fin tissue was stored in $95 \%$ ethanol and cut into parts by sterilized scissors and initially washed in distilled water and then in ethanol. Nano Drop Spectrophotometer was used to determine DNA concentration. Fifteen primers were tested for RAPD amplification of which seven primers (Table 1) exhibited good banding patterns and variability.

\section{$P C R$ amplification}

The PCR mix for $25 \mu$ containing template DNA ( $25 \mathrm{ng}$ ) $2 \mu \mathrm{l}$, de-ionized distilled water $18.8 \mu \mathrm{l}$, Taq buffer A 10X (Tris with $15 \mathrm{mM} \mathrm{MgCl2}) 2.5 \mu \mathrm{l}$, primer $(10 \mu \mathrm{M}) 1.0 \mu \mathrm{l}$, dNTPs $(2.5 \mathrm{mM}) 0.5 \mu \mathrm{l}$, Taq DNA polymerase $(5 \mathrm{U} / \mu \mathrm{l})$ $0.2 \mu \mathrm{l}$. PCR amplification was done in an oil-free thermal cycler (Gene Atlas, Japan) for 46 cycles after initial denaturing at $94^{\circ} \mathrm{C}$ for $5 \mathrm{~m}$, denaturing at $94^{\circ} \mathrm{C}$ for $1 \mathrm{~m}$, annealing at $36^{\circ} \mathrm{C}$ for $30 \mathrm{~s}$, extension at $72^{\circ} \mathrm{C}$ for $3 \mathrm{~m}$ and final extension at $72^{\circ} \mathrm{C}$ for $5 \mathrm{~m}$.

\section{Scoring and data analysis}

The amplified products were separated electrophoretically on $1 \%$ agarose gel, observed on UV-transilluminator and photographed. The photographs were critically discussed on the basis of presence (1) or absence (0), size of bands and overall polymorphism of bands. Tables were drawn up for further investigation. RAPD analysis was then combined to create a single data matrix which was used for estimating linkage distance (D) among the populations based on Nei's method (1972) by using POPGENE 32 software (version 1.31) (Yeh et al., 1997). The dendrogram was created by UPGMA method (Unweighted Pair Group Method of Arithmetic Means) (Sneath and Sokal, 1973) using linkage distances by MEGA7 software (Kumar et al., 2016). Genetic distances were computed from frequencies of polymorphic markers for estimating genetic relationship among four populations of rohu.

\section{RESULTS}

\section{RAPD polymorphism}

These seven primers showed a total of 87 bands of which 35 were polymorphic with $48.38 \%$ polymorphisms among four geographically distant $L$. rohita populations. The size of the amplified DNA fragments ranged from 400 to 1250 bp (Fig. 1 \& Table 1 ).

In addition to polymorphic bands, 8 unique bands were observed. The number, size, population and respective primer for each unique band were shown in Table 1 and Fig. 1. The unique bands were stable and specific for the respective population and thus could be used as a tool for characterization of a specific population. These results also indicate some degree of genetic diversity in four geographically distant populations of rohu. 

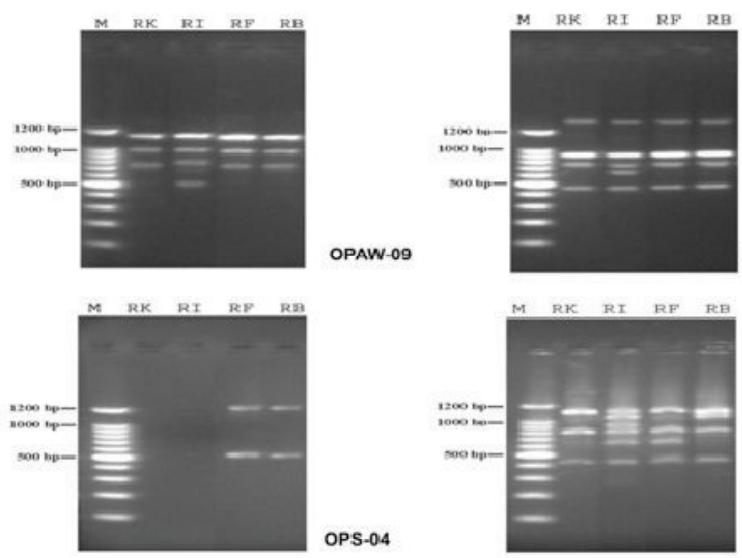

OPAK-04
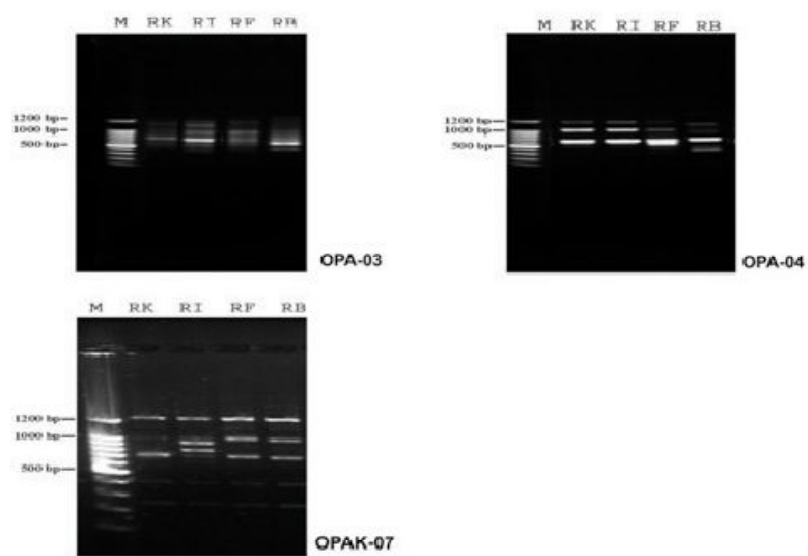

Fig 1. RAPD analysis with seven primers on four populations of $L$. rohita known as rohu Khulna= RK, rohu Indian=RI, rohu Faridpur=RF and rohu Barisal=RB. $\mathrm{M}=1 \mathrm{~kb}$ DNA ladder

\section{Genetic distances and genetic identity}

The genetic distances ranged between 0.2595 and 0.7221 (Table 2). The highest genetic distance $(0.7221)$ was found between rohu India and Barisal, while the lowest (0.2595) was among the three local populations of rohu Khulna, Faridpur and Barisal. The highest genetic identity (0.7714) was found in the three local populations of rohu Khulna, Faridpur and Barisal, and the lowest $(0.4857)$ was between rohu India and rohu Barisal.

Table 2. Genetic identity and genetic distance among the four geographically different populations of rohu

\begin{tabular}{lcccc}
\hline $\begin{array}{l}\text { Population } \\
\text { ID }\end{array}$ & $\begin{array}{c}\text { Rohu } \\
\text { Khulna }\end{array}$ & $\begin{array}{c}\text { Rohu } \\
\text { India }\end{array}$ & $\begin{array}{c}\text { Rohu } \\
\text { Faridpur }\end{array}$ & $\begin{array}{c}\text { Rohu } \\
\text { Barisal }\end{array}$ \\
\hline $\begin{array}{l}\text { Rohu } \\
\text { Khulna }\end{array}$ & $* * * *$ & 0.7143 & 0.7714 & 0.7143 \\
$\begin{array}{l}\text { Rohu } \\
\text { India }\end{array}$ & 0.3365 & $* * * *$ & 0.6571 & 0.4857 \\
$\begin{array}{l}\text { Rohu } \\
\text { Faridpur } \\
\text { Rohu } \\
\text { Barisal }\end{array}$ & 0.2595 & 0.4199 & $* * * *$ & 0.7714 \\
\hline
\end{tabular}

Nei's genetic identity (above diagonal) and genetic distance (below diagonal)

Table 1. Compilation of RAPD analysis in rohu from four geographically different locations

\begin{tabular}{|c|c|c|c|c|c|c|c|}
\hline Primer codes & $\begin{array}{l}\text { Sequences } \\
\left(5^{\prime}-3^{\prime}\right)\end{array}$ & $\begin{array}{l}\text { Size ranges } \\
\quad(b p)\end{array}$ & $\begin{array}{l}\text { Total } \\
\text { bands }\end{array}$ & $\begin{array}{c}\text { Number of } \\
\text { polymorphic } \\
\text { bands }\end{array}$ & $\begin{array}{l}\text { Number of population- } \\
\text { specific unique bands }\end{array}$ & $\begin{array}{l}\text { Polymo- } \\
\text { rphisms } \\
(\%)\end{array}$ & $\begin{array}{l}\text { Average } \% \\
\text { polymorphism }\end{array}$ \\
\hline OPAW-09 & ACT GGG TCG G & $500-1180$ & 13 & 05 & 2 in rohu Indian & 34.46 & \\
\hline OPAK-04 & AGG GTC GGT C & $490-1250$ & 17 & 01 & 1 in rohu Indian & 05.88 & 48.38 \\
\hline OPS-04 & CAC CCC CTT G & $500-1220$ & 04 & 04 & - & 100.00 & \\
\hline OPA-09 & GGG TAA CGC C & $450-1170$ & 16 & 04 & 1 in rohu Indian & 25.00 & \\
\hline OPA-03 & AGT CAG CCA C & $500-1200$ & 10 & 06 & - & 60.00 & \\
\hline OPA-04 & AAT CGG GCT G & $400-1190$ & 12 & 08 & $\begin{array}{l}1 \text { in rohu Faridpur } \\
1 \text { in rohu Barisal }\end{array}$ & 66.67 & \\
\hline OPAK-07 & CTT GGG GGA C & $700-1220$ & 15 & 07 & 2 in rohu Indian & 46.67 & \\
\hline Total & & & 87 & 35 & 8 & & \\
\hline
\end{tabular}




\section{Dendrogram (tree diagram)}

Cluster analysis on the basis of DNA fingerprinting by RAPD was carried out by POPGENE 32 (version 1.31) among 4 geographically different populations of rohu. Dendrogram based on Nei's (1972) genetic distance was separated in three major clusters viz. C1, C2 and C3. Clusters $\mathrm{C} 1$ and C2 comprised the three local populations of rohu and on the other hand, rohu Indian populations created the new distant cluster - C3.

\section{DISCUSSION}

\section{RAPD analysis}

The four populations of rohu viz. Khulna, India, Faridpur and Barisal produced different banding pattern with seven primer combinations (Fig. 1). The average polymorphism was about $48.38 \%$, revealing a moderate range of polymorphisms among these four populations of rohu.

Different average RAPD polymorphisms for rohu populations were reported by earlier studies such as 47.89\% (Fayyaz et al., 2014), 45\% (Barman et al., 2003), $27 \%$ (Khan et al., 2006) and 46.5\% (Islam and Alam, 2004). In contrast, other Indian major carps showed a higher degree of polymorphism on the basis of RAPD markers viz. 85.82\% (Basavaraju et al., 2014), 72.72\% (Rasool et al., 2013) and 54.55\% (Rahman et al., 2009). This may be due to non-conservative nature of genetic constituent that created variation in other carp except rohu.

The findings of the present study are more or less similar to the findings of previous researches. This study was conducted to estimate the genetic diversity of different rohu populations in Bangladesh in comparison with the Indian rohu population as well as within the three local rohu populations. Generally, genetic diversity among different populations is directly correlated with geographical distances (Rahman et al., 2009). Three artificially propagated rohu and rohu India had low genetic variability irrespective of geographical distribution.

\section{Analysis of unique bands}

The unique bands are found population-specific and could be used as markers for differentiation. A total of eight unique bands were observed of which six in the Indian rohu population and only one in rohu Faridpur and Barisal populations. This indicates that rohu India population is different from the other three, although significant phenotype differentiation was not found (Fig. 1 and Table 1).

\section{Phylogenetic relationships among four rohu populations}

Three rohu populations are locally cultured and they showed very little genetic distance in comparison to Indian rohu population. The geographical barriers lower the gene flow among the populations and thus genetic distances increase remarkably (Wright, 1943). There is no distinct geographical barrier among the three rohu populations and perhaps the brood fishes of that cultured rohu came from the same population or same tributary and they showed lower genetic variability among themselves. Indian rohu showed differences due to different geographical area, habitat environment and ecological parameters in India (Fig. 2).
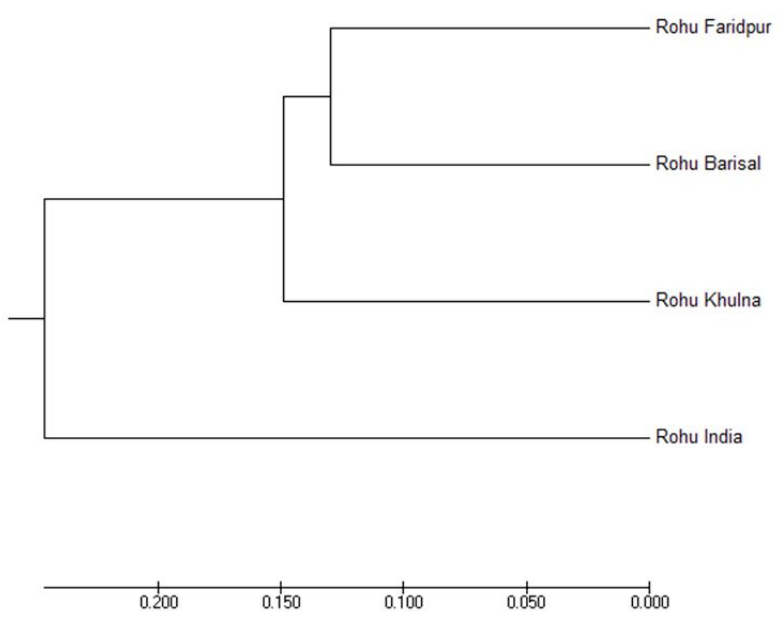

Fig 2. The dendrogram was inferred using the UPGMA method (Sneath and Sokal, 1973). The optimal tree with the sum of branch length $=0.77158333$ is shown. Dendrogram was conducted in MEGA7 (Kumar et al., 2016)

The present study and the findings of the previous ones showed that the genome of rohu is conservative, and moderate variability was found in rohu. The polymorphism of rohu below $60 \%$ indicates a low amount of genetic variability among different populations. Therefore, for an improved breeding program, distant populations are needed to avoid the inbreeding depression of rohu.

\section{CONCLUSIONS}

This research indicated that artificially propagated rohu showed a low amount of genetic diversity irrespective of geographical distribution. So for improved breeding program, these artificially propagated rohu would be a wrong choice. Natural diversified populations would be a better choice to improve the breeding program. 


\section{ACKNOWLEDGEMENTS}

We would like to express our gratitude to Professor Dr. Sheikh Shamimul Alam, Department of Botany and Director, Chromosome Research Centre, University of Dhaka for his kind help and constructive criticism in writing this paper. We are also thankful to the Ministry of Science and Technology, Government of Peoples' Republic of Bangladesh for funding this project. We are also grateful to the honourable Dr. Md. Samsul Alam, Professor, Department of Fisheries Biology and Genetics, Faculty of Fisheries, Bangladesh Agriculture University, Mymensingh.

\section{Sažetak}

\section{GENETSKA RAZLIČITOST POPULACIJA INDIJSKOG ŠARANA (Labeo rohita) ODREĐENA POMOĆU RAPD MARKERA}

Genetička raznolikost među četiri geografski udaljene populacije indijskog šarana (Labeo rohita) - rohu Khulna, rohu India, rohu Faridpur i rohu Barisal - određena je pomoću RAPD markera. Uzorak na gelu je pokazao da je populacija rohu India genetski različita od triju ostalih. Ukupno je pronađeno 87 crtica u četiri rohu populacije pri čemu je 35 crtica bilo polimorfno, što ukazuje na $48,38 \%$ polimorfizma s prosjekom od 12 crtica po početnici. Dužina amplificiranih fragmenata DNK kretala se u rasponu od 400 do $1250 \mathrm{bp}$. Osam jedinstvenih crtica je uočeno u četiri populacije od kojih je šest pronađeno u rohu India populaciji. Genetska udaljenost je bila najviša $(0,7221)$ i genetska identičnost je bila najniža $(0,4857)$ između populacija rohu India i rohu Barisal. Među tri lokalne populacije najniža genetska udaljenost i najviša genetska identičnost utvrđena je između populacija rohu Khulna i rohu Faridpur. UPGMA filogenetsko stablo odijelilo je četiri populacije indijskog šarana $u$ tri glavna odjeljka - C1, C2 i C3. Rohu Indija nalazi se na potpuno drugačijem odjeljku C3, rohu Khulna je smještena $u$ $\mathrm{C2}$, a ostale dvije populacije u C1 odjeljak.

\section{Ključne riječi: RAPD, genetska različitost, Labeo rohita}

\section{REFERENCES}

Akter, S., Sultana, S., Khan, M. S. R., Nahiduzzaman, M., Hossain, M. A. R., Alam, M. S. (2010): Genetic Characterization of Critically Endangered Puntiussarana (Hamilton) and the Exotic Barbonymusgonionotus (Bleeker) (Cyprinidae: Cypriniformes) by DNA Fingerprinting. International Journal of BioSciences, Agriculture and Technology, 2, 3, 21-27.

Almeida, F. S., Fungaro, M. H. P., Sodre, L. M. K. (2001): RAPD and isoenzyme analysis of genetic variability in three allied species of catfish (Siluriformes: Pimelodidae) from the Tibagi River, Brazil. Journal of Zoology, 253, 1, 113-120.

Barman, H. K., Barat, A., Yadav, B. M., Banerjee, S., Meher, P. K., Reddy, P. V. G. K., Jana, R. K. (2003): Genetic variation between four species of Indian major carps as revealed by random amplified polymorphic DNA assay. Aquaculture, 217, 1, 115-123.

Basavaraju, Y., Reddy, A. N., Rajanna, K. B., Chethan, N. (2014): Random amplified polymorphic DNA (RAPD) analysis of three stocks of Labeo fimbriatus from Indian peninsula. Global journal of Bio-Science and Biotechnology, 3, 3, 278-283.

Dayu, L., Dahai, K., Qianqian, Y., Xiaowen, S., Liqun, L. (2007): Microsatellite DNA marker analysis of genetic diversity in wild common carp (Cyprinus carpio L.) populations. Journal of Genetics and Genome, 34, 11, 984-993.

Doyle, J. J. (1987): A rapid DNA isolation procedure for small quantities of fresh leaf tissue. Phytochemical Bulletin, 19, $11-15$.

FAO (2006): Cultured Aquatic Species Information Programme Labeo rohita (Hamilton, 1822). Food and Agriculture Organization of the United Nations (FAO), Rome.

Fayyaz, R., Qureshi, N. A., Shakeela, P. (2014): Genetic variation among the wild and hatchery raised populations of Labeo rohita (Hamilton, 1822) revealed by RAPD markers. International Journal of Biosciences, 5, 12, 237 249.

FRSS (2016): Fisheries Statistical Report of Bangladesh. Fisheries Resources Survey System (FRSS), Department of Fisheries, Bangladesh. Volume 32, 57 pp.

Islam, M. S., Alam, M. S. (2004): Randomly amplified polymorphic DNA analysis of four different populations of the Indian major carp, Labeo rohita (Hamilton). Journal of Applied Ichthyology, 20, 5, 407-412.

Khan, M., Rahman, M., Alam, M. S., Bhuiyan, M. M. H. (2006): Allozyme variation of hatchery and river populations of rohu (Labeo rohita, Hamilton) in Bangladesh. Aquaculture Research, 37, 3, 233-240.

Kumar, S., Stecher, G., Tamura, K. (2016): MEGA7: Molecular Evolutionary Genetics Analysis version 7.0 for bigger datasets. Molecular Biology and Evolution 33, 18701874.

Nei, M. (1972): Genetic distance between populations. American Naturalist, 106, 283-292.

Rahman, A.K.A. (2005): Freshwater fishes of Bangladesh, Zoological Society of Bangladesh, University of Dhaka, Dhaka, Bangladesh. 116 pp.

Rahman, S. M., Khan, M. R., Islam, S., Alam, S. (2009): Genetic variation of wild and hatchery populations of the catla Indian major carp (Catla catla Hamilton 1822: Cypriniformes, Cyprinidae) revealed by RAPD markers. 
Genetics and Molecular Biology, 32, 1, 197-201.

Rasool, F., Qureshi, N. A., Siddique, M., Ashraf, M., Ali, A., Hameed, A., Parveen, S. (2013): Clustering analysis for intraspecific variation studies amongst the populations of Cirrhinus mrigala. The Journal of Animal \& Plant Sciences, 23, 5, 1327-1332.

Schierwater, B., Streit, B., Wagner, G. P., Desalle, R. (1994): Molecular Ecology and Evolution: Approaches and Applications. Birkhauser Verlag, Basel, Switzerland. 495508 pp.
Sneath, P. H. A., Sokal, R.R. (1973): Numerical Taxonomy. Freeman, San Francisco.

Wright, S. (1943): Isolation by distance. Genetics, 28, 114138.

Yeh, Francis C., Yang, R-C., Boyle, Timothy, B.J., YE, Z-H., and Mao, Judy X. 1997. POPGENE, the user-friendly shareware for population genetic analysis. Molecular Biology and Biotechnology Centre, University of Alberta, Canada. 